\title{
The Use of Environmentally Friendly Technologies in the Construction of Road Surfaces, with the Aim of the Rational Distribution of Natural Resources in Russia
}

\author{
Elena Chernykh ${ }^{1 *}$ \\ 1 Federal State Budget Educational Institution of Higher Education, Industrial University of Tyumen, \\ Volodarskogo street 38, 652001 Tyumen, Russia \\ * E-mail: chernyheg@tyuiu.ru
}

\begin{abstract}
The subject of research in this article is recycled plastics as a leading component in pavement construction. The aim of the work was to evaluate innovative methods of using nature-saving technologies in the construction of road surfaces, with the aim of rational distribution of natural resources. The advantages of asphalt pavement are cost-effectiveness, recycling, ease of maintenance, the ability to lay asphalt on the old layer, and good adhesion. Production of asphalt with the addition of plastic is 3\% more expensive than usual, but its environmental friendliness and prospects fully compensate for the increased production costs.
\end{abstract}

Keywords: plastic, road construction, plastic waste, environmental damage, economic efficiency.

\section{INTRODUCTION}

The use of environmentally friendly and energy efficient technologies is one of the conditions for building a modern developed economy. This is also relevant for the Russian transport industry: lately, when designing and building any large-scale transport facility, specialists have to increasingly take into account the environmental component (Lysyannikov et al. 2020)

The construction and operation of highways is one of the most significant sources of potential environmental risks that negatively affect the living conditions of people. The motor road as an engineering structure significantly changes natural landscapes, the flow regime of surface and ground waters, habitats of flora and fauna, leads to changes in the microclimate of individual territories, the appearance of landslides, land erosion, changes in the coastlines of water bodies, and is also a source of noise, vibration, electromagnetic and ionizing effects on environmental components, population and wildlife. The transport complex is the largest source of toxic pollution of water, soil and air.
In the modern world, plastic is used every day. Unfortunately, people do not think about the irreparable harm that this product brings to our nature, how much it affects the ecological situation in the world. The only way out of this situation is to properly dispose of it. In this case, you can protect not only the nature, the resulting raw materials are used a second time. Recycling plastics is the only correct way to get rid of it without harming human health, animals and the environment in general (Pugin et al. 2017)

Russia faced the problem of recycling plastic waste much later than Europe: in the Soviet Union, paper was used as a packaging material much more often than plastic, and its disposal was fairly well developed. There was no legal framework, no technology, or even interest in the problem of processing plastic waste. It was only at the end of the 20th century that this problem began to be discussed taking into account world experience. However, according to the Solid Waste Journal, plastic waste makes up only $6 \%$ of the total volume of municipal solid waste, this is a special type of waste that requires different approaches by type and region of generation. 
Disposal of plastics is a problem, mainly for two reasons: the variety and complexity of the chemical composition, and the long decomposition period of the waste.

To solve this problem, a new method of using plastic waste in the creation of road surfaces was put into operation. One of the main components of the asphalt concrete mixture is bitumen, the content of which is 13-75\% (Boguslavsky 2020). Partially replacing this material with recycled plastic will solve the problem of pollution and improve the practical properties of the road (Kuang et al. 2017). The advantages and disadvantages of plastic roads are presented in Table 1.

Road pavements based on recycled plastic waste are one of the most promising areas for the development of road construction. In the near future, this direction may become one of the stable sales channels for the plastics processing business. The use of innovative materials will help reduce highway construction and maintenance costs and eliminate plastic waste in the city.

\section{MATERIAL AND METHODS}

In Russia, the technology of using plastic waste in road construction was proposed by the Open Joint Stock Company Rusnano, which developed an Innovative Road Program, during which road surfaces using plastics were to be used in Moscow and Kazan. However, the program remained at the development stage, due to the need to adjust technical regulations for the production of asphalt concrete and the operation of road surfaces based on them.

The use of technologies for the construction of road surfaces using materials obtained from the processing of plastic waste will save significant amounts on road repairs. Almost a million kilometers of highways require investments of 1-2 trillion rubles annually. At the moment, the share of modified roads with the addition of polymers in Russia is 5\%, compared with $15 \%$ in the USA and China and 20\%. Formula and many organizations are trying to find out the technology of processing innovative asphalt. It took the three co-founders of MacRebur several years to come up with the concept of plastic asphalt. In April 2016, all technologies were documented and licensed (Lysyannikov et al. 2020).

The plastic materials required for the construction of Plastic Roads consist mainly of common post-consumer products such as product packaging. The most common plastics used in product packaging are polyethylene terephthalate (PET or PIT), polypropylene (PP), and high density polyethylene (HDPE and LDPE). The main essence of the manufacturing technology is available to everyone interested. The process is as follows:

The starting material looks like a matte granule, there are millions of such microgranules (Maciejewski 2010).

According to the developers of the formula, recycled plastic replaces oil, and the secret is

Table 1. The advantages and disadvantages of plastic roads

\begin{tabular}{|c|c|c|}
\hline No. & Positive sides & Negative sides \\
\hline 1 & $\begin{array}{l}\text { Using plastic waste is a workable solution to the problem } \\
\text { we are facing. Along with this, since the bitumen used in } \\
\text { the mixture is partially replaced, this means that we use } \\
\text { less fossil fuels. Again, this is another significant positive in } \\
\text { the struggle to save our planet. }\end{array}$ & $\begin{array}{l}\text { Plastic is a material that can be a health problem for } \\
\text { humans and animals. It can leach, we can consume it if } \\
\text { the asphalt breaks, and this can lead to a wide range of } \\
\text { health problems. }\end{array}$ \\
\hline 2 & $\begin{array}{l}\text { It is an environmentally friendly way of using waste, } \\
\text { preventing waste from ending up in landfills. However, } \\
\text { where it can really stand out is how plastic roads, } \\
\text { especially those made entirely of plastic, can completely } \\
\text { change our lifestyles. }\end{array}$ & $\begin{array}{l}\text { Among the disadvantages of the coating: } \\
\text { - the cost is } 3 \% \text { higher than the usual asphalt concrete } \\
\text { pavement; } \\
\text { - deterioration of performance at high temperatures; } \\
\text { - lack of a regulatory framework for the implementation } \\
\text { of coverage (Boguslavsky L.A.2020). }\end{array}$ \\
\hline 3 & $\begin{array}{l}\text { Plastic roads are becoming reusable as they are easy } \\
\text { to remove, recycle and repurpose. This process is much } \\
\text { less intrusive than traditional roads and can help the } \\
\text { environment in many ways, in particular by helping to } \\
\text { reduce greenhouse gas emissions. }\end{array}$ & $\begin{array}{l}\text { Production requires a lot of plastic waste - a separate } \\
\text { waste disposal system is needed. }\end{array}$ \\
\hline 4 & $\begin{array}{l}\text { Traditionally, we lay pipes and cables under roads. } \\
\text { However, plastic roads can help make this process much } \\
\text { easier. The hollow space in the structure can aid in the } \\
\text { routing of cables and pipes. Along with this, they can store } \\
\text { water, and this can also help reduce flooding, surface } \\
\text { water and road safety. }\end{array}$ & \\
\hline
\end{tabular}




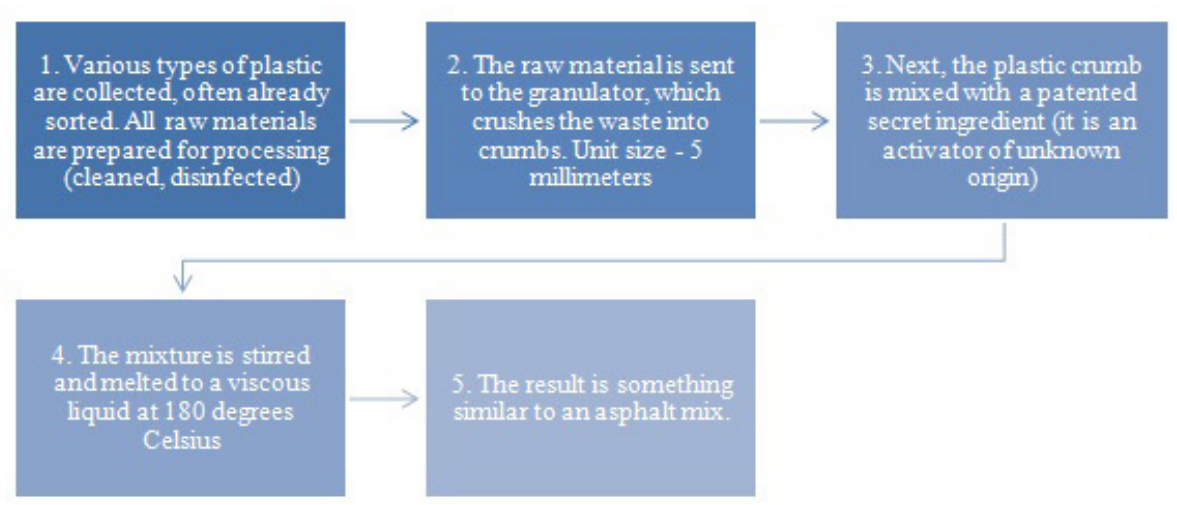

Fig. 1. The main essence of manufacturing technology

bitumen. The melting temperature is 60 degrees Celsius lower than the traditional one, so less energy and heat is required, which also has a positive effect on the environment. The use of plastic in the composition of asphalt concrete does not change the technological scheme of its production. The technological process of obtaining an asphalt concrete mixture with the addition of plastic waste is shown in Figure 2.

In order to develop the direction of plastics processing in road construction, the road laboratory of the Tyumen Industrial University conducted research on asphalt concrete samples, which used plastic waste.

Plastics of groups 1 and 4 were selected for the study in a 50/50 ratio. The choice is justified by the low toxicity when they are heated (the preparation of the asphalt concrete mixture took place in a closed room) and the melting point of the plastics. The standard bitumen mix was mixed with $2 \%$ plastic by weight of bitumen.

The heating temperature of the initial mineral raw materials and bitumen for the preparation of asphalt concrete was set at $150{ }^{\circ} \mathrm{C}$. This made it possible to completely melt the plastic of the 4th group in bitumen and transfer the plastic of the 1 st group to a plastic state. Fine-grained asphalt concrete of type B of the first grade was used as a comparison sample. Figure 3 shows the study area - the Uvat district of the Tyumen region, where a road was built from construction waste using plastic waste.

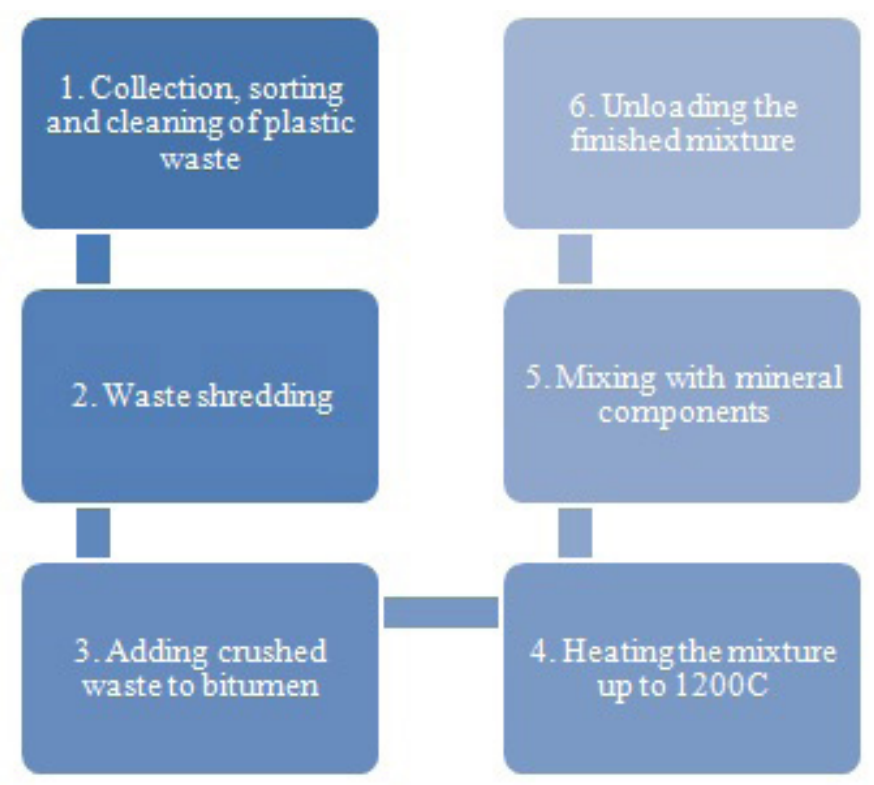

Fig. 2. Technological stages of the production of asphalt mix with the addition of plastic waste 


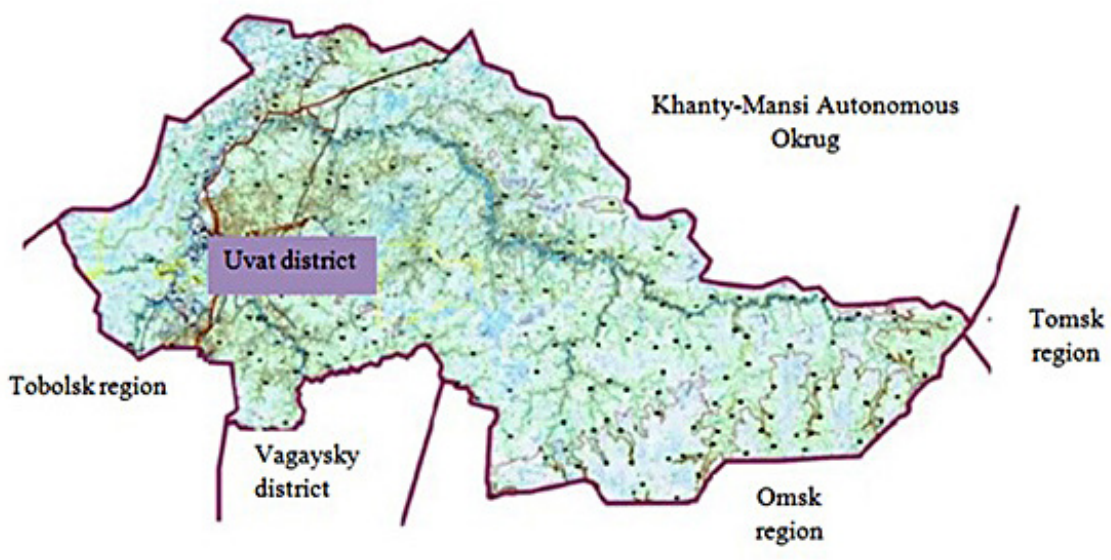

Fig. 3. Uvat district of the Tyumen region

\section{RESULTS}

Preliminary laboratory studies have shown that when using plastics in the composition of asphalt concrete, it is possible to obtain compositions that are not inferior in their characteristics to asphalt concrete based on natural raw materials. In appearance, the samples with the addition of plastic do not differ from the samples obtained by traditional technology. Samples of asphalt concrete with added plastic are shown in Figure 4.

Compared to plastics and glass, rubber has disadvantages when used in harsh climates, since the operating temperature range is lower, but the life of the roadway is longer than that of recycled plastics (Table 2).

Preliminary laboratory studies have shown that when using plastics in the composition of asphalt concrete, it is possible to obtain compositions that are not inferior in their characteristics to asphalt concrete based on natural raw materials.

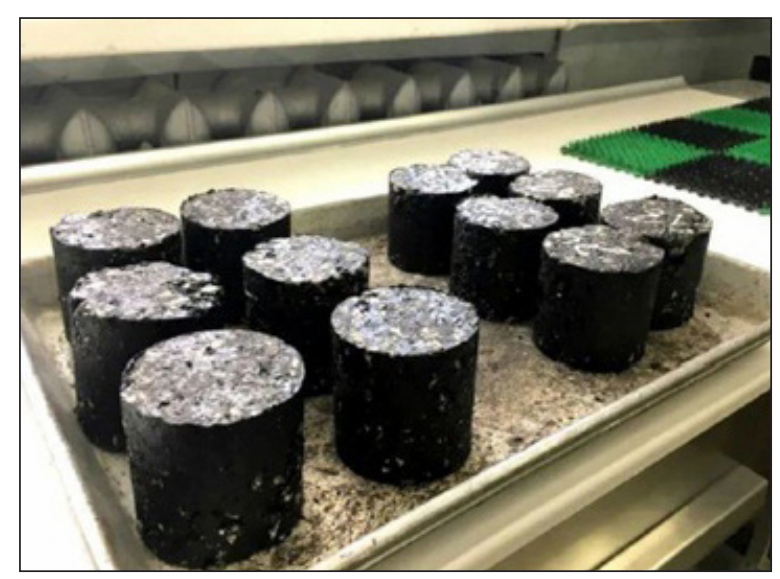

Fig. 4. Appearance of asphalt concrete samples with the addition of plastic

\section{Compressive strength:}

- at a temperature of $20^{\circ} \mathrm{C}$, the indicators of samples with plastic were $5.91 \mathrm{MPa}$, in contrast to the indicators of control samples $4.61 \mathrm{MPa}$;

- at a temperature of $50^{\circ} \mathrm{C}$, the indicators of samples with plastic were $1.50 \mathrm{MPa}$, in contrast to the indicators of control samples $1.32 \mathrm{MPa}$;

- at a temperature of $0^{\circ} \mathrm{C}$, the indicators of samples with plastic were $9.88 \mathrm{MPa}$, in contrast to the indicators of control samples of $9.50 \mathrm{MPa}$;

The shear stability by the coefficient of internal friction according to the results of the study for the indicators of samples with plastic was $0.91 \mathrm{MPa}$, in contrast to the indicators of the control samples $0.87 \mathrm{MPa}$.

The adhesion of bitumen to the mineral part is the same for all samples - the mineral part is covered by more than $3 / 4$ of the surface (Li et al. 2019).

Such important indicators as compressive strength, shear stability, have better values compared to the control samples (without plastic). This testifies to the improved performance of the road surface, extended service life of the road surface. Consider a practical example of the construction of a road surface, which includes recycled plastic, using the example of a large oil region - the Tyumen region, which includes the Uvat region. In the Uvat district, at $382 \mathrm{~km}$ of the Tyumen region, it is planned to build a $25 \mathrm{~km}$ long road surface in 2023, which will include recycled plastic.

Rosavtodor approved a pilot project for the construction of plastic roads in Russia. The government has already allocated funds for this pilot project, and the Ministry of Transport emphasized that in the near future, about $15-20 \%$ 
Table 2. Physical and technical characteristics of recycled waste

\begin{tabular}{|c|c|c|c|}
\hline $\begin{array}{c}\text { Physical and technical } \\
\text { characteristics }\end{array}$ & Glass & Plastic & Rubber \\
\hline Bulk density, $\mathrm{kg} / \mathrm{m}^{3}$ & 240 & 220 & 250 \\
\hline Dry heat conductivity, $\mathrm{W} /(\mathrm{m} \mathrm{K})$ & 0.08 & 0.04 & 0.02 \\
\hline $\begin{array}{l}\text { Thermal conductivity under } \\
\text { operating conditions } \mathrm{B}, \mathrm{W} /(\mathrm{m} \mathrm{K})\end{array}$ & 0.085 & 0.050 & 0.035 \\
\hline Compressive strength, $\mathrm{MPa}$ & $\begin{array}{l}0.79-1.98 \text { (depending } \\
\text { on the seal) }\end{array}$ & $\begin{array}{c}0.64-1.84 \text { (depending on } \\
\text { the seal) }\end{array}$ & $\begin{array}{c}0.31-2.03 \text { (depending on } \\
\text { the seal) }\end{array}$ \\
\hline Operating temperature range & ${ }^{\circ} \mathrm{C}$ from -200 to +550 & $\begin{array}{l}{ }^{\circ} \mathrm{C} \text { from }-40 \text { to }+80 \\
\text { (performance degradation } \\
\text { at high temperatures) }\end{array}$ & ${ }^{\circ} \mathrm{C}$ from -30 to +50 \\
\hline Frost resistance, brand & F100 & F80 & F40 \\
\hline $\begin{array}{l}\text { Short-term water absorption at } \\
\text { full immersion for } 24 \text { hours, \% }\end{array}$ & 1.5 & 1.6 & 2.0 \\
\hline Flammability level & Not flammable & Combustible & Combustible \\
\hline Service life of the roadway & Up to 12 years old & Up to 10 years & Up to 11 years old \\
\hline
\end{tabular}

of new highways in Russia will be built from recycled plastic if the technology is implemented in Russia.

The main difficulties in the construction of such plastic roads in Russia are the harsh climatic zones and significant fluctuations in summer and winter temperatures. If in Europe freezing temperatures in winter are rare, then in Russia for 3-4 months a year there will be a cooling down to minus 20-30 degrees, or even lower. It is currently unknown how plastics behave in such extreme conditions. Another difficulty is the use of reagents and deicing salts on Russian roads. In Europe, the use of these chemicals is prohibited by law, but in Russia in difficult climatic conditions it is not known whether plastic retains its performance characteristics without the use of such reagents. Based on the totality of all previously made calculations, we found out the cost of building a road surface according to the traditional and innovative method with a length of one kilometer, it is 336805,28 and 346909,44 dollars, respectively.

Consequently, the cost of a $25 \mathrm{~km}$ road surface will be:

- According to the traditional method: $336805,28 * 25=8420131,99$ USD

- By innovative method:

$$
346909,44 * 25=8672735,95 \text { USD }
$$

- Accordingly, the mass of plastic used to replace bitumen on a $25 \mathrm{~km}$ road surface is: $47.505 * 25=1187.625$ tons.

In the Uvat district, at $382 \mathrm{~km}$ of the Tyumen region, a $25 \mathrm{~km}$ road was built from construction waste using 1.2 million tons of waste. This saved
1.2 million tonnes of bitumen and, most importantly, 40 hectares of land that would have been required for waste disposal. About 47 tons of garbage were consumed per kilometer.

\section{CONCLUSIONS}

In accordance with the general situation, on the basis of all previous calculations, it is concluded that the advantages of using plastic in road construction are twofold. Both for the environment and for the economy due to the fact that the waste that needs to be recycled (plastic bottles, glasses, bags) turns into a building material, that is, a useful raw material. On the positive side, it can also be noted that the coating production temperature will decrease from 160 to $120^{\circ} \mathrm{C}$, which contributes to significant energy savings, reduces greenhouse gas emissions into the air, significantly increases the service life of new asphalt, moreover, over time, when cracks appear in the asphalt, repairs are carried out by heating and redistributing plastic.

The study showed that the production of asphalt with the addition of plastic is $3 \%$ more expensive than usual, but its environmental friendliness and prospects fully compensate for the increased production costs. The light weight of the plastic road slabs and the simplicity of their installation will significantly reduce the economic costs of their transportation. Another distinctive feature is the ability to lay asphalt on the old layer, good adhesion properties, improved performance of the road surface, extended service life of the 
road surface compared to the traditional method of creating an asphalt concrete mixture.

The widespread introduction of the proposed technology will simultaneously solve the problem of recycling plastic waste and improve the performance of asphalt concrete.

\section{REFERENCES}

1. Abou-Senna H., Radwan E., Westerlund K., Cooper C.D. 2013. Using a traffic simulation model (VISSIM) with an emissions model (MOVES) to predict emissions from vehicles on a limited-access highway. Journal of the Air \& Waste Management Association, 63(7), 819-831.

2. Arabani M., Mirabdolazimi S.M. 2011. Experimental investigation of the fatigue behaviour of asphalt concrete mixtures containing waste iron powder. J. of Materials Science and Engineering, 528(10-11), 3866-3870.

3. Boguslavsky L.A. Plastic Roads. Materials of the XII International Student Scientific Conference "Student Scientific Forum". https://scienceforum. $\mathrm{ru} / 2020 /$ article/2018019201"> https://scienceforum.ru/2020/article/2018019201

4. Csikós A., Varga I. 2012. Real-time modeling and control objective analysis of motorway emissions. Procedia-Social and Behavioral Sciences, 54, 1027-1036.

5. Dolia A.G., Shatvorian D.A., Smirnova D.V., Zhukov I.P. 2017. Effektivnoe ispol'zovanie porod shakhtnykh otvalov vdorozhnom stroitel'stve. Efficient use of mine waste rock in road construction. Vestnik Donbasskoi natsional'noi akademii stroitel'stva i arkhitektury, 2(124), 94-101.

6. Federal environmental regulatory documents. 2013. Quantitative chemical analysis of soils. Methodology for measuring the mass fraction of petroleum products in soil and soil samples, 16(1-2), 21-98.

7. Gao J., Wang H., Bu Y., You Z., Hasan M.R.M., Irfan M. 2018. Effects of coarse aggregate angularity on the microstructure of asphalt mixture. Construction and Building Materials, 183, 472-484. https:// doi.org/10.1016/j.conbuildmat.2018.06.170

8. https://macrebur.com/ - MacRebur . The Plastic Road Company

9. Kogbara R.B., Masad E.A., Kassem E., Scarpas A.T., Anupam K. 2016. A state-of-the-art review of parameters influencing measurement and modeling of skid resistance of asphalt pavements. Construction and Building Materials, 114, 602-617. https:// doi.org/10.1016/j.conbuildmat.2016.04.002.

10. Kotliarskii E.V., Kochnev V.I., Davliatova
D.I. 2015. Avtomatizirovannoe proektirovanie asfal'tobetonnykh smesei s zadannymi svoistvami. Computer-aided design of asphalt concrete mixtures with specified properties. Nauka i tekhnika v dorozhnoi otrasli, 1(71), 27-29.

11. Kuang D., Zhang B., Jiao Y., Fang J., Chen H., Wang L. 2017. Impact of particle morphology on aggregate-asphalt interface behavior. Construction and Building Materials, 132, 142-149. https://doi. org/10.1016/j.conbuildmat.2016.11.132.

12. Li I., Li P., Su J., Xue Y., Rao W. 2019. Effect of aggregate contact characteristics on densification properties of asphalt mixture. Construction and Building Materials, 204, 691-702. https://doi. org/10.1016/j.conbuildmat.2019.01.023.

13. Liu P., Hu J., Falla G.C., Wang D., Leischner S., Oeser M. 2019. Primary investigation on the relationship between microstructural characteristics and the mechanical performance of asphalt mixtures with different compaction degrees. Construction and Building Materials, 223, 784-793. https://doi. org/10.1016/j.conbuildmat.2019.07.039.

14. Lysyannikov A.V., Egorov A.V., Lysyannikova N.N., Shram V.G., Kovaleva M.A., Lynev A.S., Kaizer Y.F. 2019. Polymer materials from recycled plastic in road construction. Published under licence by IOP Publishing Ltd Journal of Physics: Conference Series, 1399, 4.

15. Maciejewski M. 2010. A comparison of microscopic traffic flow simulation systems for an urban area. Transport Problems, 5, 27-38.

16. Niu S., Ning Y., Lu C., Han, K., Yu H., Zhou Y. 2018. Esterification of Oleic Acid to Produce Biodiesel Catalyzed by Sulfonated Activated Carbon from Bamboo. Journal Energy Conversion and Management, 163, 59-65.

17. Pugin K.G., Iushkov V.S. 2017. Otkhody metallurgicheskikh predpriiatii dlia sozdaniia tsvetnogo asfal'tobetona. Waste from metallurgical enterprises for the creation of colored asphalt concrete. Ekologiia i promyshlennost. Rossii, 21(5), 4-7.

18. Simakova T.V., Skipin L.N., Evtushkova E.P., et al. 2018. Monitoring of reclaimed land in Tyumen region. Espacios, 39(14), 22.

19. Yusuf M. 2018. Determination of Free Fatty Acid and Saponification Number at PT. Oil Palm Research Center, Medan. Sustainable Cities and Society Journal, 41, 220-226

20. Zhang W. 2017. Effect of tack coat application on interlayer shear strength of asphalt pavement: A state-of-theart review based on application in the United States. International Journal of Pavement Research and Technology, 10(5), 434-445. https:// doi.org/10.1016/j.ijprt.2017.07.003. 